УДК 81'282.4: 811.162.1(477)

https://doi.org/10.31548/philolog2021.01.049

\title{
THE POLISH LANGUAGE IN THE PETTY NOBILITY VILLAGE OF SLOBIDKA RAKHNIVSKA IN UKRAINIAN PODOLIA
}

\author{
O. V. ZAKHUTSKA, PhD: Doctor of Arts in Linguistics, Associate Professor, \\ National University of Life and Environmental Sciences of Ukraine \\ E-mail: oksana.zov@gmail.com \\ https://orcid.org/0000-0002-9766-0683
}

\begin{abstract}
The article presents the phonetic and inflectional features of the Polish language spoken in the petty nobility village of Slobidka Rakhnivska in Podolia in comparison with other Polish dialects in Ukraine. Vast material for analysis comes from field research conducted in the village by Marta Gugała and Aleksandra Krawczyk-Wieczorek in 2003 and by myself in 2009 under the supervision of Professor Janusz Rieger.

Local Poles experienced collectivization, famine in 1933 and 1947, arrests, shootings and deportations in 1935-38; some rescued themselves by declaring their nationality as Ukrainian. Such historic and sociolinguistic circumstances inevitably influenced the number of Poles in Slobidka and the use of Polish. Nowadays it is little spoken on a daily basis. The dominant language in use is Ukrainian, while Polish, however, remains a sacred language and a means of private communication with senior people.

The conducted analysis showed that due to close Polish and Ukrainian as well as Russian linguistic contacts foreign influences are noticeable on different linguistic levels: phonetic and inflectional. The word stress, however, remains fixed, on the penultimate syllable, even in borrowings. At the same time, the research confirmed earlier observations: Polish of the local descendants of the petty nobility is more similar to the regional variety of the standard Polish, spoken in the South-Eastern Borderlands and described by Zofia Kurzowa, than to other Polish peasant dialects in the neighboring territories. For example, there are no forms with realization of suffix $\nmid / />\mathrm{n}$ in the words wzieła, wzioł, zdjoł; no realization -it, $-\mathrm{y} \nmid>-\mathrm{u}$ in the words bił, kupił; no dissimilation kk > tk like in letki, mientki or $\mathrm{dl}>\mathrm{gl}$ in gliatego, glia and others. A separate issue for discussing and further analysis is features, known in Polish ethnic dialects, and characteristic of Ukrainian at the same time.
\end{abstract}

Keywords: Polish in Ukraine, petty nobility, peasant, dialect, linguistic contacts, phonetics, inflection.

Introduction. After the World War II, in the 1970s Professor Viacheslav Verenich and his team from Minsk started conducting research of Polish dialects in Ukraine. The results of these activities were the published in two volumes of Польские говоры СССР (edited by V. Verenich, 1973) and in the first few volumes of Studia nad polszczyzną kresową, which began to appear in print in Poland in the early 1980s. Further systematic dialectological research on the rural Polish language spoken in the territory of Ukraine left to the river Zbruch was initiated on a larger scale by Professor Janusz Rieger from Warsaw after 1989. It resulted in the collection of vast material that attracted the researchers' attention by its specific phonetic and morphological features, vocabulary, word formation and syntax due to close Polish and Ukrainian as well as Russian linguistic contacts.

Recent research and publications. At the dawn of the $21^{\text {st }}$ c. there were published three monographic studies on phonetic and inflectional systems of a few Polish peasant dialects in Ukraine: of Korchunok in Zhytomyr region by Sergiusz Rudnicki [9], of Oleshkivtsi by Iwona Cechosz-Felczyk [1] and of Zelena by Ewa Dzięgiel [3] in Podolia. Minor initial studies on the so-called petty nobility villages revealed its different character, though our knowledge about it is still insufficient, limited to separate articles [cf. 3; 5; 7; 8] and one later monograph on the vocabulary of one dialect [11]. Thus, it requires further theoretical and practical studying on a vast material basis from different places.

The village of Slobidka Rakhnivska (Pol. Stobódka Rachnowiecka) is situated $25 \mathrm{~km}$ north of Kamianets-Podilskyi. According to Stownik geograficzny... [2, p. 352-353], at the end of the $19^{\text {th }}$ century, it had 20 houses and belonged to the community in Rakhnivka. At that time, in these places there lived 550 people, mostly of Polish nationality. At the beginning of the $21^{\text {st }}$ century, according to official statistics, in Slobidka Rakhnivska there were 593 inhabitants. The vocabulary of the village has already been described from the point of view of functioning Ukrainian and Russian borrowings parallelly to their native Polish equivalents [10].

The purpose of this article is to present the phonetic and inflectional features of Polish spoken in the petty nobility village of Slobidka Rakhnivska in Podolia in comparison with other Polish dialects in Ukraine.

Material and methods. The study is based

(c) O. V. Zakhutska

«International journal of philology» | «Міжнародний філологічний часопис» Vol. 12, № 1, 2021 
on materials recorded in the village by Marta Gugała and Aleksandra Krawczyk-Wieczorek in 2003 and by myself in 2009 during field research under the supervision of Prof. J. Rieger. Respondents: WJ29, LU30, EZ59, WU69, AN70; the numbers indicate the year of birth.

The comparison with other Polish dialects is based on two monographic studies: Polszczyzna Lwowa i Kresów południowowschodnich do 1939 roku by Zofia Kurzowa [6] and Polszczyzna na Ukrainie by Ewa Dzięgiel [4] as well as on minor articles about Polish dialects published in: Język polski na Ukrainie w końcu XX wieku, t. I, 2002; Język polski dawnych kresów wschodnich, t. I-III, 1996-2006; Studia nad polszczyzną kresową, t. IX, 1999.

Results. Poles from Slobidka Rakhnivska, as well as from many other places in Ukraine, experienced collectivization, famine in 1933 and 1947, arrests, shootings and deportations in 1935-38. Some rescued themselves by declaring their nationality as Ukrainian. For this reason, and because of mixed marriages, it is difficult to define the exact number of Poles in Slobidka. According to the respondents, Poles previously constituted half of the population, probably descendants of petty nobility. This is evidenced by their statements: $u$ nas mówili, że Poliacy to szliachta, to pany, bardzo delikatne liudzie; u nas mówio, że w Poliaków wszystkich jest błenkitna krew, pańska krew, że to szliachta tutaj mieszka, as well as Polish surnames ending in -ski, -cki: Użycki, Winnicki, Zawalski, Bujnicki, etc.

Due to the relatively small number of inhabitants, there was neither a school nor a church in the village before the war. Some children went to schools in nearby villages, others studied at home. Ukrainian primary school appeared after the World War II and secondary school only in the 1980s. Currently, once a week a teacher from Poland, who works regularly in the nearby town of Dunaivtsi, conducts Polish language lessons for willing children.

In 1991-95, the local Roman Catholics built a church in Slobidka at their own expense. Priests who regularly come from Kamianets-Podilskyi hold masses in two languages: Polish and Ukrainian, so that everyone can understand.

Local Poles little speak Polish on a daily basis. The dominant language in use is Ukrainian, while Polish, however, remains a sacred language. The older generation understands, can read and write in Polish, and some of them can and use Polish brought from home well. Younger residents start to study standard Polish, often go to Poland to visit their families, to sightsee and participate in language courses.

\section{Word stress}

The word stress is fixed; it does not differ from the Polish standard stress, falls on the penultimate syllable. It is true also for borrowings from Ukrainian or Russian adapted or partially adapted phonetically and morphologically, e.g. nazad, nikuda, werstat.

\section{Phonetics}

Influence of stress on the vowels. The narrowing of unstressed vowels occurs in different positions and to a different degree, e.g. do Cze $e^{y}$ stochowa, drze wjanna, piniendzy, pszynica, (ja) mówi, robi, ludzi, zaśpiewam pieśni, na stroni, $w$ krajiny. Forms like: praco ${ }^{u}$ wali, jo ${ }^{u}$, pa ${ }^{\circ}$ mientam appeared several times.

Narrowing of the stressed vowel $o$ before the nasal consonant was recorded once in: ko 'ńmy, and the reduction of the stressed $y$ to $e-$ twice in: by $y^{e}$ li, prze nim.

Realization of *é. At present sound $e$ appears in the stressed position in place of *é, e.g. mlieko, chlieb, wiem, sierp, kobieta, once as $i$ : wim. Pronunciation $i, y<{ }^{*} e$ in the words spiwali, syrowatka, szyroki may depend on the tendency to narrow the unstressed e regardless of origin (a phenomenon known also to ethnic Polish dialects) and supported by the Ukrainian influence (співали, сироватка, широкий). A similar situation occurs in other Polish dialects in Ukraine, regardless of their state origin.

Realization of *ir, *yr. The letter combinations *ir, * $y r$ give contemporary form er, e.g. ser, serce, cerkiew, śmierć, umierać, zbierać, pierogi, pierszy. Differently the old soft sonant $r$ is realized like $\operatorname{ir}(z)$ : in the word wirzch, and $y r$ in the word cztyry, also supported by the Ukrainian influence (dial. um upu).

Realization of old long $\boldsymbol{o}$. The most common is realization of old long $o$ like $u$ similarly to standard Polish and other Polish dialects in Ukraine. However, sound 0 appeared several times in the words młocili, mjod, mogł, wor, perhaps because of alignment to the forms miodu, mogła / mogli, worek.

Articulation of nasal vowels. Distribution of nasality also takes place before fricative consonants, e.g. ksionżka, sonsiadka, mienso, cienżko, while at the end of the word there is denazalization, e.g. sie, (ja) liubie, (ja) chce, targano słomo, pod głowe. In parallel, although rarely, there are forms with a pronounced nasality at the end of words, e.g. kupie, zmuszę, dalieką, lubią (exceptionally before $s$ : wąska). Before $t$, as in standard Polish, there is absence of nasality, e.g. wzieła, wziot, ujot, uklinkneli. A similar articulation of nasal vowels occurs in many other dialects in Ukraine.

Prosthetic consonants. Prosthetic $w$ rarely precedes the initial vowel $O$, as in Ukrainian: wona, wony, wono, which may be quite common in some peasant dialects in Ukraine. At the same time, an iota often precedes the initial $i$ and $i$ in the mid-voice, e.g. jim, jich, moji, stoji, słojiku, poji, 
zaspokojiś, krajiny; this phenomenon is known to the dialects of eastern Poland and is common in Ukrainian.

Letter combination $-e j$ at the end of words. It occurs in a nationwide form, e.g. prendzej, wiencej, takiej, ukraińskiej, or narrowed, e.g. Rachnowieckij, pol'skij, sowieckij. Narrowing of $e$ with the disappearance of vocal $j$ we have in the word dali (although it may be a borrowing from Ukrainian далі).

Soft labial consonants. Before the vowels $e, o$, a soft labials are pronounced with a greater or lesser distribution of softness and its separation in the form of $j$ or ${ }^{j}$, what is typical for standard Polish and supported by the Ukrainian influence, e.g. bjały, bjoro, objecali, pjec, wjeczór obok obliad, zrobliona, plierszy, wiem. There is a consequent distribution of softness after $m$ in the form of ń, e.g. pomnientała, mnieli, zmnienknie, mniodu, w mniejscu, mniasorubka. The consonant group -wn takes the form $-m n$ in the words: damny, damniej, damno, in other words, we have the realization consistent with the Polish language, e.g. na pewno, śpiewnik, cudowny.

Consonant $\boldsymbol{f}$ has the frontal-dental pronunciation in all positions, e.g. kościót, był, chodził; koło, Słobódka, nalieżało; kołchoz, pałka. Pronunciation + like [ŭ] (non-syllabic u) typical for standard Polish did not appear.

Consonant $I$ is always palatalized, e.g. liato, lion, wygliondało, alie, dalieko, Pol'ka, tyl'ko.

Consonants ś, ć, ź, dź are pronounced in different ways: as semi-palatalized, similarly to Ukrainian, e.g. jakas', babc'ia, kos'c'iół; as intermediate sounds between semi-palatalized and palatalized sounds ś, ć, ź, dź, e.g. wz"ieli, c"ierpic", dz"iec"i, wis"niami, and as totally palatalized like in standard Polish, e.g. chodzili, gdzieś, kupić. Often the degree of palatalization is difficult to determine.

Palatalization of k, g, ch > k', g', ch'. In some words there appears palatalization of the back-lingual hard $k, g$ into middle-lingual soft $k$, g', e.g. w reńkie, cygankie, pod dachiem, gieńsi, gienstyj, grzechi (parallelly to forms grzechy, orzechy, muchy). There are also forms with $k$ in place of k', e.g. cukerki, prosteńke, malieńke, take.

External sandhi. The voicing in external sandhi often appears before sonorants and vowels, e.g. pod okupacjo, skond ona, też nie wiem, ksiondz miał, tak nauczyła, jak mówie, w Żydów można kupić, z kwiatów jakich, sztanów nie było, what is characteristic to Ukrainian. Forms with lack of voicing were noted several times, e.g. brat mój, obowionzkóf jeszcze, kościołóf nie było, za Niemcóf ja pamientam.

\section{Inflection}

The category of masculine and nonmasculine personal gender. As in other dialects, the only exponent of the masculine personal gender becomes the syncretism of accusative with genitive in plural of nouns denoting masculine persons, e.g. znała chłopców, posyłali swatów, zostawili tych mężczyzn. Examples of syncretism of accusative with genitive in singular of nouns denoting feminine gender, modeled on Ukrainian, appeared in examples: matka komus' jej oddała, żeb ja jej pamnientała.

In Slobidka Rakhnivska, there exists the unified form of the personal pronoun oni: oni chłopcy, oni dziewczenta, oni liampy, oni walionki. Plural forms of the past tense end in unified ending -li, e.g. dzieci bawili sie, kobiety szyli, koszyki byli. However, there were inconsistently noted remnants of the non-masculine gender, e.g. dzieci cieszyły sie, suknie były krótsze, and conjunction którzy (although in relation to dzieci) along with the more frequent które and exceptional form starzy. This may prove the existence of other, though vanishing, exponents of the category of masculine personal $~$ nonmasculine personal gender, and in the case of the ending ty about the influence of analogous Ukrainian forms (тішилися, були).

Accusative of feminine gender nouns in singular. The standard Polish ending $-e(-e)$ is common, e.g. na msze, chate, wode, renke. Besides that, Ukrainian ending $-u$ appeared several times, e.g. pokropiła wodu, dały Komuniju, zapamientała pies'niu, tu ukraińsku szkołu, s'wiencono w niedz'ieliu.

Dative of nouns in plural. Under the influence of Ukrainian the borrowed ending -am became common, e.g. dz"iec"iam, gos"c"iam, liudz"iam.

Instrumental of nouns in plural. In this case, the standard ending -ami/-mi occurs regularly, e.g. Poliakami, nami, aniołami, górami, reńkami, katolikami, liudz"mi. The Ukrainian ending -amy we noted once: swymy dziewczentamy.

The ending $-i j /-y j$ in nominative of adjectives of masculine gender in singular. As in other places, next to the standard ending $-i /-y$, e.g. aresztowany, chory, stareńki, there is often a parallel Ukrainian ending -ijj-yj, e.g. takij, bjałyj, młodyj, s'wientyj, dobryj, ładnyj.

Accusative of feminine adjectives and pronouns in singular. Next to the regular ending -ą [o], e.g. w jedno strone, swojo staro chatke, msze s'wiento, matke bosko, there are a few examples of the ending -e [e]: na goronce wode, w goronce wode, ide na msze s'wiente.

Forms of personal pronouns. The personal pronouns ja, ty, on, ono have in some inflectional cases mostly non-enclitic forms. The form jego prevails in genitive and dative, e.g. jego nie widz'iała, bardzo jego kochała, poprosiła jego; the form niego appeared once after the 
preposition: ukraszenija taki do niego; the form go was used twice: zabrali go. Similarly, in dative, nonenclitic mnie, tobie, jemu were registered, e.g. mówiła mnie babcia, tobie powiem, cos" jemu dali, wybili jemu, pomóc jemu. Enclitic forms, on the other hand, were recorded in genitive, dative and locative of possessive pronouns mój, swój, e.g. mego ojca zabrali, za mego życ"ia, w mego dz"iadz"ia, do serca swego, swego woza, swego konia.

Inflection of compound numerals. As in Ukrainian, in compound numerals usually only the last word is inflected, e.g. w czterdz"ies"c" $i$ s'iodmym roku, w czterdz"ies"c"i jakim. The inflection consistent with the standard Polish appeared only in the youngest respondent who is currently learning Polish, e.g. $w$ trzydziestym drugim roku, w trzydziestym siódmym roku.

Present tense. All forms of the first and second person in plural in the present tense in Slobidka have endings in line with the standard Polish endings (unlike other peasant dialects in Ukraine, where other endings may appear), i.e. 1 person: -my, e.g. kupimy, mamy, obchodz"imy, dostawiamy, żyjemy, mieszkamy; 2 person: -c"ie, e.g. robic"ie, s"piewac"ie, styszec"ie, pliec"iec"ie, wiez'iec"ie, klienczyc"ie.

Past tense. In the analyzed material, analytical forms of the past tense usually appear, consisting of the stem with the suffix $t$ - in

\section{References}

1. Cechosz-Felczyk, I. (2001). Polska gwara Oleszkowiec na Podolu. Fleksja imienna i werbalna [The Polish dialect of Oleshkivtsi in Podolia. Nominative and verbal inflection]. Kraków: Wydawnictwo Naukowe DWN, 192.

2. Chlebowski, B., Walewski, W. (ed.) (1888). Słownik geograficzny Królestwa Polskiego i innych krajów słowiańskich [Geographical dictionary of the Kingdom of Poland and other Slavic countries]. T. IX. Warszawa: Druk "WIEKU”, 353-353.

3. Dzięgiel, E. (2001). Polska gwara wsi Zielonej na Podolu na tle innych gwar południowokresowych. Fleksja imienna i werbalna [The Polish dialect of the village of Zelena in Podolia compared to other Polish dialects in Ukraine. Nominative and verbal inflection]. Kraków: Wydawnictwo Naukowe DWN, 209.

4. Dzięgiel, E. (2003). Polszczyzna na Ukrainie. Sytuacja językowa w wybranych wsiach chłopskich i szlacheckich [Polish in Ukraine. The linguistic situation in selected peasant and noble villages]. Warszawa: Wydawnictwo Naukowe Semper, 187.

5. Dzięgiel, E. (2017). Odmiany terytorialne i społeczne współczesnego języka polskiego na Ukrainie [Territorial and social varieties of the contemporary Polish language in Ukraine]. LingVaria. Rok XII (2017), 2 (24), 199-210. combination with the appropriate personal pronoun for all persons, e.g. (ja) zapomniała, chodz'iła, uczyła s"ie, (ty) powiedz"iała, nie widz"iała, (my, wy) chodz"ili, s'piewali, chc'ieli, zabrali. The forms like byłam, chodz'iłam, kupiłam, widz"iec"ie and stalis"c"ie, jechalis"c"ie are rare but still remind about their usage some time ago or are learnt nowadays.

Past Perfect tense. Forms of the past perfect tense are encountered, e.g. powróc"iła była, byli zaaresztowali, było nalieżało.

Conclusion and discussion. The analysis of linguistic features of Poles living in Slobidka Rakhnivka in Ukrainian Podolia confirms the earlier observations: Polish of the local descendants of the petty nobility is more similar to the regional variety of the standard Polish, spoken in the South-Eastern Borderlands, than to other Polish peasant dialects in the neighboring territories. For example, there are no forms with realization of suffix $t / l>n$ in the words wzieła, wzioł, zdjoł; no realization -it, -yt > -ut in the words bit, kupit; no dissimilation $k k>t k$ like in letki, mientki or $d l>g l$ in gliatego, glia and others. A separate issue for discussing and further analysis is features, known in Polish ethnic dialects, and characteristic of the Ukrainian language at the same time.

6. Kurzowa, Z. (1983). Polszczyzna Lwowa i Kresów południowo-wschodnich do 1939 roku [The Polish language of Lviv and the SouthEastern Borderlands until 1939]. Warszawa Kraków: Państwowe Wydawnictwo Naukowe, 551.

7. Rieger, J. (2002). Język polski na Ukrainie w XX wieku [Polish in Ukraine in the 20th century]. J. Rieger, I. Cechosz-Felczyk, E. Dzięgiel, Język polski na Ukrainie w końcu XX wieku. Cz. 1. Warszawa: Semper, 11-51.

8. Rieger, J. (2002). O różnych rodzajach polszczyzny na Ukrainie (uwagi o języku polskich wsi i przysiółków szlacheckich) [On different kinds of Polish in Ukraine (comments on the language of Polish peasant and noble villages]. „Studia dialektologiczne" II, pod red. J. Okoniowej, B. Dunaja, Kraków, 173-184.

9. Rudnicki, S. (2000). Polska gwara wsi Korczunek na Żytomierszczyźnie [The Polish dialect of the village of Korchunok in the Zhytomyr region]. Warszawa: Slawistyczny Ośrodek Wydawniczy, 199.

10.Zakhutska, O. (2011). Jeszcze o słownictwie kresowym (próba porównania idiolektów szlacheckich i chłopskich na Podolu) [Once again on vocabulary in the former Eastern Borderlands (an attempt to compare noble and peasant idioletes in Podolia)]. Język polski, XCl, 5, 352-363. 
11.Zakhutska, O. (2015). Polszczyzna drobnoszlacheckiej wsi Siaberka na Wołyniu. Słownictwo [The Polish language of petty nobility village of Siaberka in Volhynia. Vocabulary]. Warszawa: Wydawnictwo DiG, 200.

\section{ПОЛЬСЬКА МОВА ДРІБНОШЛЯХЕТСЬКОГО СЕЛА СЛОБІДКА РАХНІВСЬКА НА ПОДІЛЛІ О. В. Захуцька}

Анотація. У статті представлено фонетичні та фрлексійні особливості польської мови дрібношляхетського села Слобідка Рахнівська на Поділлі у порівнянні з іншими польськими говірками в Україні. Матеріал для аналізу зібрано під час польових досліджень, які проводили в селі Марта Гугала та Александра Кравчик-Вєчорек у 2003 році, а також автор статmі у 2009 році під керівництвом профресора Януша Рігера.

Місцеві поляки пережили колективізацію, голод 1933 р. та 1947 р., арешти, розстріли та депортації 1935-38 рр.; деякі рятували своє життя, приховуючи польське походження. Такі історичні та соціолінгвістичні обставини неминуче вплинули на кількість поляків у Слобідці та на вживання польської мови. Сьогодні у повсякденному житті місцеві жителі польської національності спілкуються переважно українською, проте польська дотепер залишається мовою релігії та особистісного спілкування старшого покоління.

Проведений аналіз показав, що завдяки тісним польсько-українським, а також російським мовним контактам іноземний вплив помітний на різних мовних рівнях: фоонетичному та фрлексійному. Наголос однак залишається фріксованим на передостанньому складі навіть у запозиченнях. У той же час дослідження підтвердило попередні спостереження: польська мова місцевих нащадків дрібної шляхти ближча до регіонального варіанту літературної польської мови, якою розмовляли поляки в Україні та яку описала Зофрія Курцова, ніж до інших, так званих хлопських, польських говірок на сусідніх територіях. Наприклад, немає форм із реалізацією суфрікса $\mathrm{t} / \mathrm{l}>\mathrm{n}$ y словах wzieła, wzioł, zdjoł; відсутня реалізація -ił, -ył > -uł у словах bił, kupił; вiдсутність дисиміляції kk $>t k$, як y letki, mientki або $d l>g l$ в gliatego, glia та ін. Окремим питанням для обговорення $i$ подальшого аналізу $\epsilon$ особливості, притаманні польським етнічним говіркам i одночасно характерні для української мови.

Ключові слова: польська мова в Україні, дрібна шляхта, «хлопи», говірка, мовні контакти, фонетика, фрлексія. 